\title{
Humoral immune response induced with dengue virus-like particles serotypes 1 and 4 produced in silkworm
}

Doddy Irawan Setyo Utomo ${ }^{1}$, Sabar Pambudi ${ }^{2}$ and Enoch Y. Park ${ }^{1,3^{*}}$

\begin{abstract}
Dengue is an arboviral disease, which threatens almost half the global population, and has emerged as the most significant of current global public health challenges. In this study, we prepared dengue virus-like particles (DENVLPs) consisting of Capsid-premembrane-envelope (CprME) and premembrane-envelope (prME) polypeptides from serotype 1 and 4, which were expressed in the silkworms using Bombyx mori nucleopolyhedrovirus (BmNPV) bacmid. 1CprME, $1 \mathrm{prME}$, 4CprME, and 4prME expressed proteins in hemolymph, and the molecular weight of the purified proteins was $55 \mathrm{kDa}$, respectively. The purified polypeptides formed spherical Dengue virus-like particles (DENV-LPs) with $\sim 30-55 \mathrm{~nm}$ in diameter. The immunoelectron microscopy (IEM) images revealed antigens to the surface of a lipid bilayer of DENV-LPs. The heparin-binding assay shows a positive relationship between absorbance and $\mathrm{E}$ protein domain III (EDIII) quantity, which is supported by the isothermal titration calorimetry assay. This indicates a moderate binding affinity between heparin and DENV-LP. The high correlation between patient sera and DENV-LP reactivities revealed that these DENV-LPs shared similar epitopes with the natural dengue virus. IgG elicitation studies in mice have demonstrated that DENV-LPs/CPrMEs elicit a stronger immune response than DENV-LP/prMEs, which lends credence to this claim.
\end{abstract}

\section{Highlights}

- Dengue virus-like particles for serotype 1 and serotype 4 (DENV-LPs/1 and DENV-LPs/4) were produced in silkworm.

- Heparin-binding assay by ELISA and ITC showed that DENV-LPs/1 and DENV-LPs/4 contain Envelope Domain III.

- DENV-LPs/1 and DENV-LPs/4 showed affinity to sera from human dengue patients and immunized mice.

Keywords: Dengue virus, Capsid, Premembrane, Envelope, Dengue virus-like particle, Silkworm

*Correspondence: park.enoch@shizuoka.ac.jp

${ }^{1}$ Laboratory of Biotechnology, Department of Bioscience, Graduate

School of Science and Technology, Shizuoka University, 836 Ohya,

Suruga-ku, Shizuoka 422-8529, Japan

Full list of author information is available at the end of the article

\section{Introduction}

Dengue fever is a significant public health issue that has been reported in the Americas, Africa, Southeast Asia, Europe, the Western Pacific, and the Eastern Mediterranean. This arboviral disease is endemic in more than 100 countries, and approximately 96 million infected individuals have symptoms of varying severities. There has been a growing public health concern about dengue fever 
in the last few decades. The World Health Organization (WHO) named it one of the top ten global health threats in 2019, highlighting the critical need for a safe and effective vaccine. Despite numerous attempts, identifying the best candidate for a dengue vaccine continues to be a difficult task due to some critical factors that must be considered (Bhatt et al. 2021; Redoni et al. 2020).

Dengue virus (DENV) is the etiological agent for dengue fever. DENV belongs to the Flaviviridae family and Flavivirus genus. It has four antigenically distinct serotypes and antigenically similar yet genetically diverse.. Adaptive immunity induced by one DENV serotype does not provide long-term protection against infection with the other three heterotypic DENVs There is 70\% sequence homology between DENV serotype 1-4 (DENV-1-DENV-4), which means that numerous immunogenic epitopes are conserved at some level. DENV is an enveloped virus with a single positive-strand RNA genome that encodes three structural proteins, Capsid (C), premembrane (prM), and envelope (E), as well as seven nonstructural proteins (NS1, NS2A, NS2B, NS3, NS4A, NS4B, and NS5) (Redoni et al. 2020; Yousaf et al. 2018).

Based on a 70-year study that examined the spread of DENV worldwide, the most reported strains were DENV-1, DENV-2, and DENV-3, and the least frequently recorded was DENV-4. Although DENV-4 was the first serotype of dengue to diverge in phylogenetic investigations of the Flavivirus genus, it spread slowly worldwide. DENV-1 and DENV-4 cause dengue fever with different degrees of severity. When DENV-1 infection was compared to DENV-4 infections, the duration of fever, which essentially correlates with the severity of the illness, was much longer for DENV-1. DENV-1 infection was also associated with more severe clinical manifestations than DENV-4 infection. Primary DENV-4 infection is a relatively mild sickness, but primary DENV-1 infection has more severe symptoms (Nishiura and Halstead 2007; Sang et al. 2019; Villabona-Arenas and Zanotto 2013).

Virus-like particles (VLPs) are viruses with a shell but no genetic material. VLPs may mimic the organization and conformation of wild viruses because they contain multiprotein determinants. The organization and conformation of native viruses can be used to explore virus infection mechanisms and stimulate the host immune system to produce robust immune responses (Roldao et al. 2010). Furthermore, VLPs do not cause infections because they lack the viral genome. These properties of VLPs make them potential vaccine candidates that may be more efficient and safer than conventionally attenuated or inactivated viruses (Noad and Roy 2003).

Two successful approaches have been applied to produce recombinant VLPs of flaviviruses, including capsid-premembrane-envelope (CprME) protein genes and pre-membrane-envelope (prME) proteins in cis as well as in trans from plasmid vectors. Both types of approaches should result in the formation of particles. Although the $\mathrm{C}$ protein is not required to form particles, the inclusion of $C$ protein may have a stabilizing effect on VLP assembly. Capsid proteins can be arranged in one, two, or three layers, depending on their size. Some single-layer VLPs can contain more than one structural protein, whereas others cannot. When compared to the structure of single-protein VLPs (which is relatively simple), multiprotein VLPs (which contain several distinct capsid layers) have additional structural components (Krol et al. 2019; Nooraei et al. 2021).

Baculovirus expression vector system (BEVS) is a high-level mass production tool for recombinant proteins in silkworm. This enables us to express eukaryotic recombinant proteins with posttranslational modifications similar to mammals'. The number of recombinant proteins produced by silkworm-BEVS in silkworm larvae is frequently significantly higher than that produced by Sf9-BEVS in cultured cells (Kato et al. 2010; Vipin Kumar Deo 2012). Feeding silkworms is exceptionally inexpensive, with a total cost of approximately USD 20 for twenty larvae. Thus, it costs slightly more than USD 20 to obtain approximately $1 \mathrm{mg}$ of active Protein kinase B alpha $(\mathrm{PKB \alpha})$ (Maesaki et al. 2014). This approach is comparable in cost to an expression system based on Escherichia coli. Furthermore, because silkworms have low-cost productivity equal to the $E$. coli expression system, protein production can be quickly and inexpensively scaled up. This expression system is favorable for vaccine development (Fujita et al. 2020).

Previously, we have successfully expressed DENV-LPs serotype 2 (DENV-LP/2CprME and /2E) and DENV-LPs serotype 3 (DENV-LP/3prME and /3CprME) by removing capsid-anchor in the $\mathrm{C}$ region (Utomo et al. 2019, 2020). In this study, we prepared DENV-LPs consisting full-length of Capsid-Premembrane-Envelope (1CprME and 4CprME) and Premembrane-envelope (1prME and 4prME) polypeptides from serotypes 1 and 4 , which were expressed using Bombyx mori nucleopolyhedrovirus (BmNPV) bacmid in silkworms. We observed the formation of VLPs, confirmed envelope domain III (EDIII) of DENV using a heparin-binding assay by ELISA and ITC, reactivity toward dengue patient sera, and demonstrated the elicitation of antibody production in a mouse model.

\section{Materials and methods}

\section{Construction and preparation of recombinant BmNPVs}

The C-prM-E and prM-E polypeptide coding sequences (GenBank: DENV-1 KM204119, DENV-4 KR011349, Genewiz, New Jersey, USA) were used. A linker sequence 
(GGGGSGGGGS) and HA-tag sequence (YPYDVPDYA) for DENV-1 constructs, a Strep tag-II sequence (WSHPQFEK) for DENV-4 constructs, and a FLAG-tag sequence (DYKDDDDK) for both serotype constructs were fused at the C-terminus using a template (the synthetic gene described above) by polymerized chain reaction (PCR) with a template for the coding sequence of DENV-1CprME and DENV-4CprME. Used primers were 1CprME-F, 1CprME-R-EcoRI, 4CprME-F, 4CprMER-EcoRI (Table 1). To isolate the DENV-1prM-E and DENV-4prM-E coding sequences, a primer set (1prME-F, 1prME-R-EcoRI, 4prME-F, 4prME-R-EcoRI, Table 1) was used. PrimeSTAR Max DNA Polymerase (TaKaRa, Kyoto, Japan) has been used for the PCR process with composition $25 \mu \mathrm{l}$ PrimeSTAR Max Premix $(2 \times), 10 \mathrm{pmol}$ forward primer, $10 \mathrm{pmol}$ reverse primer, $200 \mathrm{ng}$ DNA template, and sterilized $\mathrm{ddH}_{2} \mathrm{O}$ up to $50 \mu \mathrm{l}$. The PCR steps began with an initial denaturation at $98{ }^{\circ} \mathrm{C}$ for $10 \mathrm{~s}$, followed by 35 cycles of $98^{\circ} \mathrm{C}$ for $10 \mathrm{~s}, 55^{\circ} \mathrm{C}$ for $5 \mathrm{~s}$, and $72{ }^{\circ} \mathrm{C}$ for $20 \mathrm{~s}$, and finished with $72{ }^{\circ} \mathrm{C}$ for $3 \mathrm{~min}$ for the final extension. The PCR process was carried out using a thermal cycler (TaKaRa). Each construct was ligated into the pFastbac1 vector (Thermo Fisher Scientific K. K., Tokyo, Japan), and the resulting vector was transformed into E. coli $\mathrm{BmDH} 10 \mathrm{bac} \mathrm{CP}^{-} \mathrm{Chi}^{-}$. BmNPV/1CprME, BmNPV/4CprME, BmNPV/1prME, and BmNPV/4prME bacmids were isolated from white colonies. Ten or twenty $\mu \mathrm{g}$ of each recombinant BmNPV bacmid DNA was mixed with $0.1 \%$ chitosan (Sigma-Aldrich, Tokyo, Japan) and $2 \%(\mathrm{w} / \mathrm{v})$ of 2-( $N$-morpholino) ethanesulfonic acid (MES) buffer (Sigma-Aldrich). The recombinant BmNPV bacmid DNA mixture was incubated for approximately $45 \mathrm{~min}$ at room temperature (RT) before injection. Subsequently, $\sim 50 \mu$ of the mixture was injected into a fifthstage instar silkworm larva (Ehimesansyu, Ehime, Japan).

Table 1 Used primers

\begin{tabular}{ll}
\hline Name & $\mathbf{5}^{\prime} \mathbf{3}^{\prime}$ \\
\hline 1CprME-F & TAA TGG ATC CAT GAA CAA TCA GCG CAA A \\
1CprME-R-ECoRI & TAA TGA ATT CTC AAG CGT AGT CCG GAA CA \\
1 prME-F & TAA TGG ATC CAT GTTTCA CCT GAC CAC CAG GGG \\
1 prME-R-ECoRI & TAA TGA ATT CTC AAG CGT AGT CCG GAA CA \\
4CprME-F & TAA TGG ATC CAT GAA CCA GAG GAA AAA AGT \\
4CprME-R-ECoRI & TAA TGA ATT CTC ATT TTT CGA ACT GGG GG \\
4prME-F & TAA TGG ATC CAT GTT CCA TCT CTC GAC GCG TGAT \\
4prME-R-ECoRI & TAA TGA ATT CTC ATT TTT CGA ACT GGG GG \\
pFastBaC1-F & TAT TCC GGA TTA TTC ATA CC \\
pFastBaC1-R & ACA AAT GTG GTA TGG CTG ATT \\
pUC/M13-F & CCC AGT CAC GAC GTT GTA AAA CG \\
pUC/M13-R & AGC GGA TAA CAATTT CAC ACA GG
\end{tabular}

Underlines indicate restriction enzyme cleavage sites
The hemolymph containing recombinant BmNPV was collected from the larvae 6-7 days post-injection (dpi) and mixed with 1-phenyl-2-thiourea at $1 \mathrm{mM}$, with aliquots of hemolymph stored at $-80^{\circ} \mathrm{C}$ before use (Boonyakida et al. 2021; Suhaimi et al. 2019; Utomo et al. 2019, 2020).

\section{Expression and purification}

Ten fifth-stage instar silkworm larvae (Ehimesansyu) were injected with 100-fold diluted hemolymph in phosphate-buffered saline (PBS) $(137 \mathrm{mM} \mathrm{NaCl}, 2.7 \mathrm{mM} \mathrm{KCl}$, $8 \mathrm{mM} \mathrm{Na}_{2} \mathrm{HPO}_{4}$, and $2 \mathrm{mM} \mathrm{KH}_{2} \mathrm{PO}_{4}, \mathrm{pH}$ 7.4). They were fed a synthetic diet (Silkmate S2, Nosan Co., Yokohama, Japan). After $5 \mathrm{dpi}$, the hemolymph was collected by cutting the larva's leg. The hemolymph was diluted tenfold with $50 \mathrm{mM}$ Tris- $\mathrm{HCl}$ (pH 7.5) containing $300 \mathrm{mM} \mathrm{NaCl}$ before being applied to DDDDK-tagged protein purification gel column chromatography (Medical \& Biological Laboratories, Nagoya, Japan). The column was washed with $50 \mathrm{mM}$ Tris- $\mathrm{HCl}(\mathrm{pH} 7.5)$ containing $300 \mathrm{mM}$ $\mathrm{NaCl}$. The proteins were eluted with $0.17 \mathrm{M}$ glycine $-\mathrm{HCl}$ buffer $(\mathrm{pH}$ 2.3). The eluents were neutralized immediately with $1 \mathrm{M}$ Tris- $\mathrm{HCl}(\mathrm{pH} 8.0)$. Ultrafiltration was used to concentrate the eluents using an Amicon Ultra$0.5 \mathrm{~mL}$ Centrifugal Filter Unit with an Ultracel-30 K membrane (Merck Japan, Tokyo, Japan). A BCA protein assay kit was used to determine the protein concentration (Thermo Fisher Scientific K. K.).

\section{Western blot analysis}

To separate the proteins, $10 \%$ or $12 \%$ sodium dodecyl sulfate-polyacrylamide gel electrophoresis (SDS-PAGE) was used and subsequently subjected to western blotting by blotting the proteins trapped in acrylamide gel onto an Immobilon-P PVDF (polyvinylidene fluoride) membrane (Merck Japan) using the Mini Trans-Blot Electrophoretic Transfer Cell (Bio-Rad, Hercules, CA, USA). After blotting, the membrane was blocked in Tris-buffered saline with $0.1 \%$ Tween 20 detergent (TBST) (pH 7.6) with 5\% skim milk (FUJIFILM Wako Pure Chemical). Then the membrane was incubated in 10,000-fold diluted mouse anti-HA tag antibody (Medical and Biological Laboratories) for DENV-1 constructs and anti-strap tag II antibody (Medical and Biological Laboratories) for DENV-4 constructs. Alternatively, 1500-fold diluted specific serotype monoclonal anti-envelope antibodies, antiE DENV-1 E29 clone (BEI Resources, Virginia, US) for DENV-1 constructs, and anti-E DENV-4 E42 clone (BEI Resources) for DENV-4 constructs were used as the primary antibodies. Anti-E DENV-2 3H5-1 clone (BEI Resources) and anti-E DENV-3 E1 clone (BEI Resources) antibodies were also used to assess cross-reactivity between serotypes for all purified proteins. $C$ protein was 
also confirmed using an anti-capsid polyclonal antibody (GeneTex, CA, USA). After three washes with TBST, the membrane was incubated for one hour with 10,000-fold diluted anti-mouse IgG antibody conjugated to horseradish peroxidase (HRP) (FUJIFILM Wako Pure Chemical). The specific bands were discovered using a Fluor-S MAX Multi-Imager (Bio-Rad).

\section{Heparin-binding assay by ELISA}

The heparin-binding assay by ELISA was performed with modifications as previously described (Utomo et al. 2019, 2020). Six ng/ml diluted biotin-labeled heparin (SigmaAldrich Japan) and $1.8 \mathrm{ng}$ of heparin were immobilized into blockless avidin plate (Sumitomo Bakelite, Tokyo, Japan) wells and washed three times with PBS. For negative control, $2 \mu \mathrm{g}$ of BSA was used. Purified proteins of 1 CprME, 1prME, 4CprME, and 4prME at various concentrations $(0.5,1,5$, and $10 \mathrm{~g} / \mathrm{ml})$ were added to wells at corresponding quantities, incubated at room temperature for one hour, and then washed with PBST. After serial washing, a 1000-fold diluted rabbit anti-DENV E polyclonal antibody (GeneTex) was added, followed by a 1000 -fold diluted HRP-conjugated anti-rabbit IgG antibody (FUJIFILM Wako Pure Chemical). To stop the

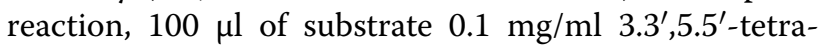
methylbenzidine (TMB) in $100 \mathrm{mM}$ sodium acetate $\left(\mathrm{CH}_{3} \mathrm{COONa}\right), \mathrm{pH} 6.0$, was added to each well with $0.2 \%$ (v/v) $30 \%$ hydrogen peroxide, and $50 \mu \mathrm{l}$ of $1 \mathrm{~N} \mathrm{H}_{2} \mathrm{SO}_{4}$ was added. The absorbance was estimated at $450 \mathrm{~nm}$.

\section{Isothermal titration calorimetry assay for heparin-binding to DENV-LPs}

The binding affinities of DENV-LP to heparin were determined using isothermal titration calorimetry (ITC) (MicroCal iTC200, Malvern Panalytical Ltd, Enigma Business Park, UK). Titrations were performed at a temperature of $25{ }^{\circ} \mathrm{C}$ by injecting $2 \mu \mathrm{l}$ aliquots of $1000 \mu \mathrm{M}$ ligand dissolved in $1 \times$ PBS buffer into a cell containing $10 \mu \mathrm{M}$ DENV-LP. The heat release was recorded, and the titration data were analyzed with MicroCal Origin ITC software (Malvern Panalytical Ltd). Thermodynamic parameters were determined by fitting experimental data with nonlinear least-squares using the one-set sites binding model (Duff et al. 2011; Ikegaya et al. 2021).

\section{Human DENV-infected sera interaction with DENV-LPs}

Direct ELISA was carried out with modifications as previously described (Utomo et al. 2019, 2020). An interaction between antigens, 1CprME, 1prME, 4CprME, and 4 prME, and patient sera were detected using a direct ELISA method. Dengue patient sera [rapid diagnostic test NS1 $(+)$ ] were used. Sera were obtained from the Centre of Pharmaceutical and Medical Technology, National
Research and Innovation Agency, Jakarta, Indonesia. Protocols of the collection were reviewed and approved by the Health Research Ethics Committee-University of Indonesia and Cipto Mangunkusumo Hospital (HRECFMUI/CMH) (approval no. KET-1358/UN2.F1/ETIK/ PPM.00.02/2020).

Each diluted sample of 1CprME, 1prME, 4CprME, and 4prME, $100 \mu \mathrm{l}$ of $20 \mathrm{ng} / \mathrm{ml}$ in coating buffer $(0.05 \mathrm{M}$ carbonate-bicarbonate, $\mathrm{pH}$ 9.6), was applied to a 96-well ELISA plate and incubated overnight at $4{ }^{\circ} \mathrm{C}$. After incubation, the coating solution was discarded, and a $100 \mu \mathrm{l}$ blocking solution (5\% skim milk in PBS) was added to each well, followed by $1 \mathrm{~h}$ at $37^{\circ} \mathrm{C}$ incubation. The plates were then washed serially with PBST buffer before adding $100 \mu \mathrm{l}$ of 1:50 patient sera in PBS. Plates were then incubated at $37{ }^{\circ} \mathrm{C}$ for $1 \mathrm{~h}$ before being washed three times with washing buffer and before the addition of $100 \mu$ of 1:5000 anti-human IgG-HRP conjugated antibody. Plates were then incubated at $37{ }^{\circ} \mathrm{C}$ for $1 \mathrm{~h}$ and washed, and $50 \mu \mathrm{l}$ of TMB substrate was applied and incubated for 10 min before being stopped with $50 \mu \mathrm{l}$ of $1 \mathrm{M} \mathrm{H}_{2} \mathrm{SO}_{4}$. The absorbance was measured at $450 \mathrm{~nm}$.

\section{Immunoelectron microscopy}

Immunoelectron microscopy (IEM) was carried out as previously described (Utomo et al. 2020) with modifications. The purified antigen sample was added to the $\mathrm{Cu}$-grid transmission electron microscopy (TEM) (Nisshin EM Co., Ltd., Tokyo) and incubated for $30 \mathrm{~s}$ at room temperature, washed with $30 \mu \mathrm{l}$ of PBS, and incubated for $30 \mathrm{~s}$, repeated three times. BSA $(30 \mu \mathrm{l}$ of $2 \% \mathrm{v} / \mathrm{v})$ was used for blocking after adding a purified antigen sample and washed three times with PBS. The $\mathrm{Cu}$-grid was washed in stages. The first and secondary antibodies were antiE rabbit polyclonal antibody (FUJIFILM Wako Pure Chemical) diluted 30 times, and goat anti-rabbit IgGconjugated (FUJIFILM Wako Pure Chemical) gold nanoparticles diluted 50 times, respectively. The $\mathrm{Cu}$ grid was treated with $1 \%$ phosphotungstic acid and analyzed with a JEM-2100F TEM system (JEOL Ltd., Tokyo, Japan).

\section{Mice immunization}

Mouse immunization was carried out as previously described (Utomo et al. 2020) with modifications. In this study, $50 \mathrm{BALB} / \mathrm{c}$ mice (PT Indoanilab, Bogor, Indonesia) aged 4-6 weeks were divided into ten groups: (i) negative control (PBS), (ii) immunized with alhydrogel as an adjuvant, (iii) immunized with 1CprME, (iv) immunized with 1 CprME + adjuvant, (v) immunized with 1prME, (vi) immunized with 1 prME + adjuvant, (vii) immunized with 4CprME, (viii) immunized with 4CprME + adjuvant, (ix) immunized with 4prME, and $(x)$ immunized with 
4 prME + adjuvant. All mice were kept in a temperature-controlled, light-cycled room and were divided into ten groups based on the immunogen. Each mouse was immunized three times intraperitoneally within 2 weeks with $50 \mu \mathrm{g}$ of purified 1CprME, 1prME, 4CprME, and 4prME proteins with alhydrogel adjuvant. Blood samples were collected via the tail vein on Days 0,16 , and 30 , and sera were isolated and stored at $-80{ }^{\circ} \mathrm{C}$. All animal procedures were conducted in compliance with established guidelines from the Animal Laboratory of Center of Pharmaceutical and Medical Technology, National Research and Innovation Agency, Indonesia. Animal experiment protocols were reviewed and approved by the Health Research Ethics Committee-University of Indonesia and Cipto Mangunkusumo Hospital (HREC-FMUI/CMH) (approval no. KET-721/UN2.F1/ETIK/PPM.00.02/2021). The interaction between antigens, 1CprME, 1prME, $4 \mathrm{CprME}$, and 4prME, with the respective mice sera, was detected using a direct ELISA method.

One hundred $\mu \mathrm{l}$ of $20 \mathrm{ng} / \mathrm{ml}$ diluted antigen, respectively, in coating buffer $(0.05 \mathrm{M}$ carbonate-bicarbonate, $\mathrm{pH}$ 9.6), was applied to a 96-well ELISA plate and incubated overnight at $4{ }^{\circ} \mathrm{C}$. After incubation, the coating solution was discarded, and a $100 \mu \mathrm{l}$ blocking solution (5\% skim milk in PBS) was added to each well, followed by $1 \mathrm{~h}$ at $37^{\circ} \mathrm{C}$ incubation. The plates were then washed serially with PBST buffer before adding $100 \mu \mathrm{l}$ of $1: 10$ mice sera in PBS. Plates were then incubated at $37{ }^{\circ} \mathrm{C}$ for $1 \mathrm{~h}$ before being washed three times with washing buffer and before the addition of $100 \mu \mathrm{l}$ of 1:5000 anti-mouse IgG-HRP conjugated antibody. Plates were then incubated at $37{ }^{\circ} \mathrm{C}$ for $1 \mathrm{~h}$ and washed, and $50 \mu \mathrm{l}$ of TMB substrate was applied and incubated for $10 \mathrm{~min}$ before being stopped with $50 \mu \mathrm{l}$ of $1 \mathrm{M} \mathrm{H}_{2} \mathrm{SO}_{4}$. The absorbance was measured at $450 \mathrm{~nm}$.

\section{Results}

Expression of 1CprME, 1prME, 4CprME and 4prME polypeptides in silkworm

DENV structural proteins are composed of a $\mathrm{C}$, and two membrane proteins, prM and $\mathrm{E}$ translated at the beginning of the polyprotein in the order C-prM-E. BmNPV/1CprME (Fig. 1a), BmNPV/1prME (Fig. 1b), BmNPV/4CprME (Fig. 1c), and BmNPV/4prME (Fig. 1d) bacmids were injected into silkworm larvae, and the silkworm hemolymph was collected at 5 dpi. The expression of 1 CprME, 1prME, 4CprME, and 4prME in hemolymph samples was confirmed, with molecular weights of $55 \mathrm{kDa}$ at the $\mathrm{E}$ protein (Additional file 1: Fig. S1), which corresponded to the estimated weight.

\section{Purification of $1 \mathrm{CprME}$, 1prME, 4 CprME and 4prME polypeptides}

The 1CprME, 1prME, 4CprME, and 4prME polypeptides were purified by affinity chromatography and confirmed by western blot using mouse anti-HA tag antibody for DENV-1 constructs (Fig. 2a, b) and anti-strap tag II antibody for DENV-4 constructs, which showed bands of size $55 \mathrm{kDa}$ at elution fractions $(\mathrm{Fr})$, respectively. To determine whether the purified 1CprME, 1prME, 4CprME, and 4prME polypeptides contained E proteins, western blotting was performed using serotypespecific monoclonal anti-envelope antibodies, an anti-E DENV-1 E29 clone for DENV-1 constructs, and an antiE DENV-4 E42 clone for DENV-4 constructs. All of the constructs' bands were confirmed to be approximately $55 \mathrm{kDa}$ (Fig. 2e, f). These results demonstrate that the $\mathrm{E}$ proteins were present in the purified $1 \mathrm{CprME}$, 1prME, $4 \mathrm{CprME}$, and 4 prME polypeptides. The $\mathrm{C}$ protein was confirmed using anti-capsid pAb, which showed a band of size $14 \mathrm{kDa}$ only in CprME constructs (Fig. 2g). AntiE-DENV-1 E29 clone, anti-E-DENV-2 3H5-1 clone, anti-E-DENV-3 E1 clone, and anti-E-DENV-4 E42 clone antibodies were used to investigate the cross-reactivity of all purified proteins. Specific bands for 1CprME (Fig. 3a), 1prME (Fig. 3b), 4CprME (Fig. 3c), and 4prME (Fig. 3d) could not be detected using the specific serotype antibodies. These results indicate no cross-reactivity between specific serotype antibodies and all the constructs.

\section{Morphology of $1 \mathrm{CprME}, 1 \mathrm{prME}, 4 \mathrm{CprME}$ and $4 \mathrm{prME}$ polypeptides}

IEM was used to confirm the morphology of the polypeptides 1 CprME, 1prME, 4CprME, and 4prME. Spherical structures with sizes ranging from 30 to $55 \mathrm{~nm}$ were observed (Fig. 4a-d), supported by data from dynamic light scattering (Fig. 4e-h). The IEM observation revealed that the particles were lipid bilayer-structured spherical, with some immunogold bound to their surface. The presence of anti-dengue $E$ protein in gold nanoparticles bound to the surface of spherical structures indicates that the particles contain dengue $\mathrm{E}$ protein on the surface of the VLPs. According to these results, the 1CprME, 1prME, 4CprME, and 4prME polypeptides expressed in silkworms can generate VLPs of Dengue-1 and -4 (DENV-LPs/1CprME, DENV-LPs/1prME, DENVLPs/4CprME, and DENV-LPs/4prME).

\section{Heparin-binding assay of the DENV-LPs/1CprME, /1 prME, /4CprME, and /4prME}

A heparin-binding assay was performed to confirm the expression of EDIII on the surface of DENV-LPs. The binding assay of the purified DENV-LPs/1CprME, 

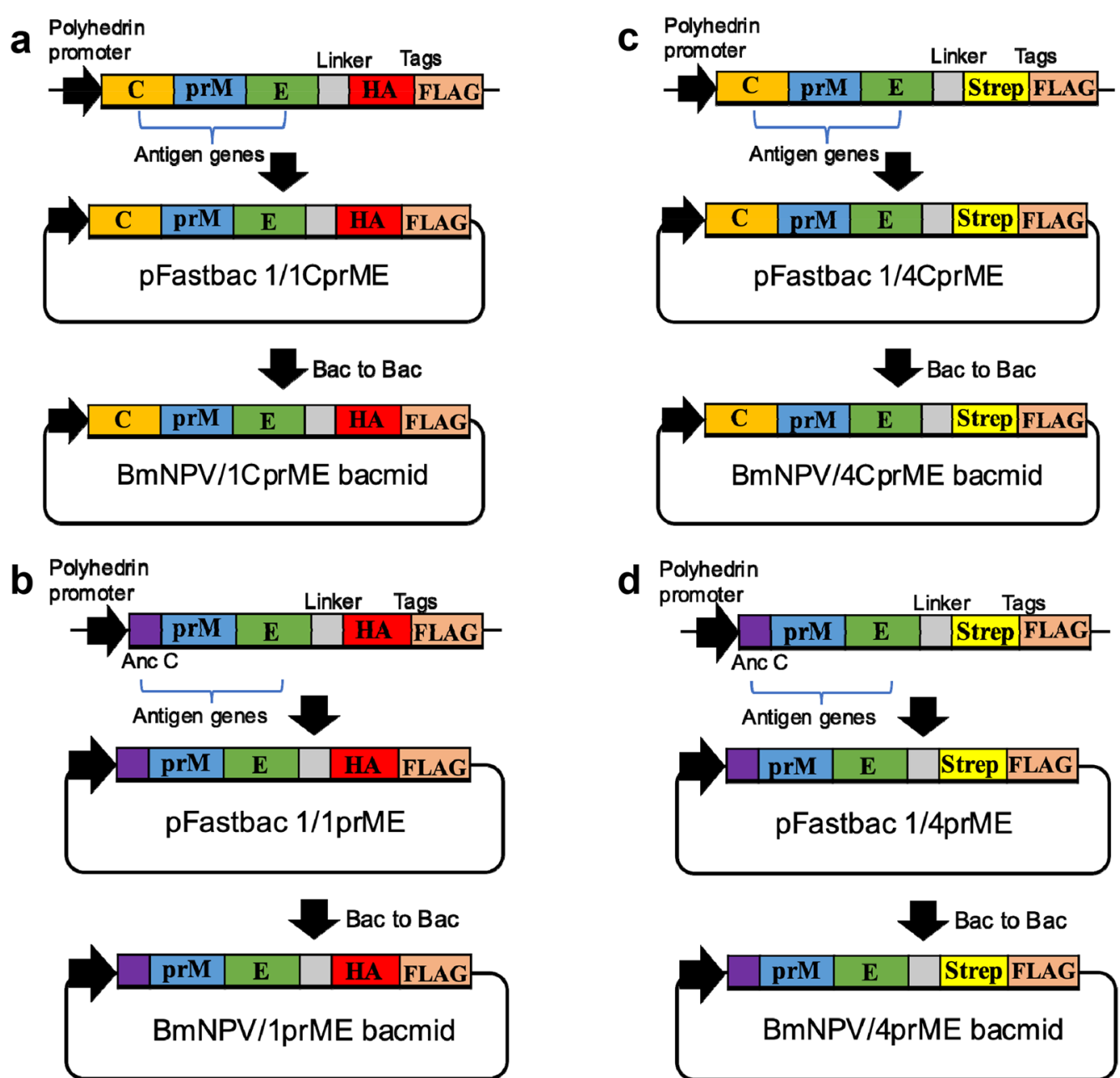

Fig. 1 Construction of recombinant dengue virus structural proteins expressed in this study. a 1 CprME, b 1 prME, c 4CprME, and d 4 prME polypeptides of DENV-1 and 4 were expressed in silkworms as a fusion protein with HA + FLAG tags for DENV-1 and Strep-tag II + FLAG tags for DENV-4

/1prME, /4CprME, and /4prME was performed using heparin-immobilized microtiter plates. In ELISA, the absorbance increased proportionally to the presence of E (Fig. 5a). These results indicate that the EDIII domain is present on the surface of the DENV-LPs/1CprME, /1prME, /4CprME, and /4prME.

\section{Isothermal titration calorimetry assay for heparin-binding to DENV-LPs}

Binding activities of DENV-LPs/1CprME, /1prME, /4CprME, and /4prME toward heparin were investigated by ITC (Fig. 5b-e). Heparin binds to DENV-LPs with $K_{\mathrm{D}}$ values of $197-952 \mathrm{nM}$ and $\Delta G$ values from -8.8 to - $9.3 \mathrm{kcal} \mathrm{mol}^{-1}$ (Table 2). $K_{\mathrm{D}}$ values, $235.2 \mathrm{nM}$ of DENVLPs/1CprME or 197.6 nM of /4CprME were 4-folds lower than 952.4 nM of DENV-LPs/1prME or $819.7 \mathrm{nM}$ of $/ 4$ prME, suggesting CprMEs are higher affinity to heparin than prMEs, which are the similar results of ELISA (Fig. 5a). $\Delta G$ value of DENV-LPs/1CprME or /4CprME was similar to DENV-LPs/1prME or /4prME, indicating that the heparin binding to the EDIII on DENV-LPs/CprMEs and DENV-LPs/prMEs has a similar spontaneously binding.

\section{Human DENV-infected sera interaction with DENV-LPs} Purified DENV-LPs/1CprME, /1prME, /4CprME, and /4prME were characterized for their antigenicity toward the patient sera by direct ELISA. As shown in ELISA analysis, DENV-LPs/1CprME, /1prME, /4CprME, and /4prME showed reactivity to patient sera compared to PBS and the rabbit anti-DENV E polyclonal antibody as a positive control (Fig. 6a). DENV-LPs/1CprME, /1prME, /4CprME, and /4prME to patient sera showed significantly high responses compared to anti-E antibody. The 


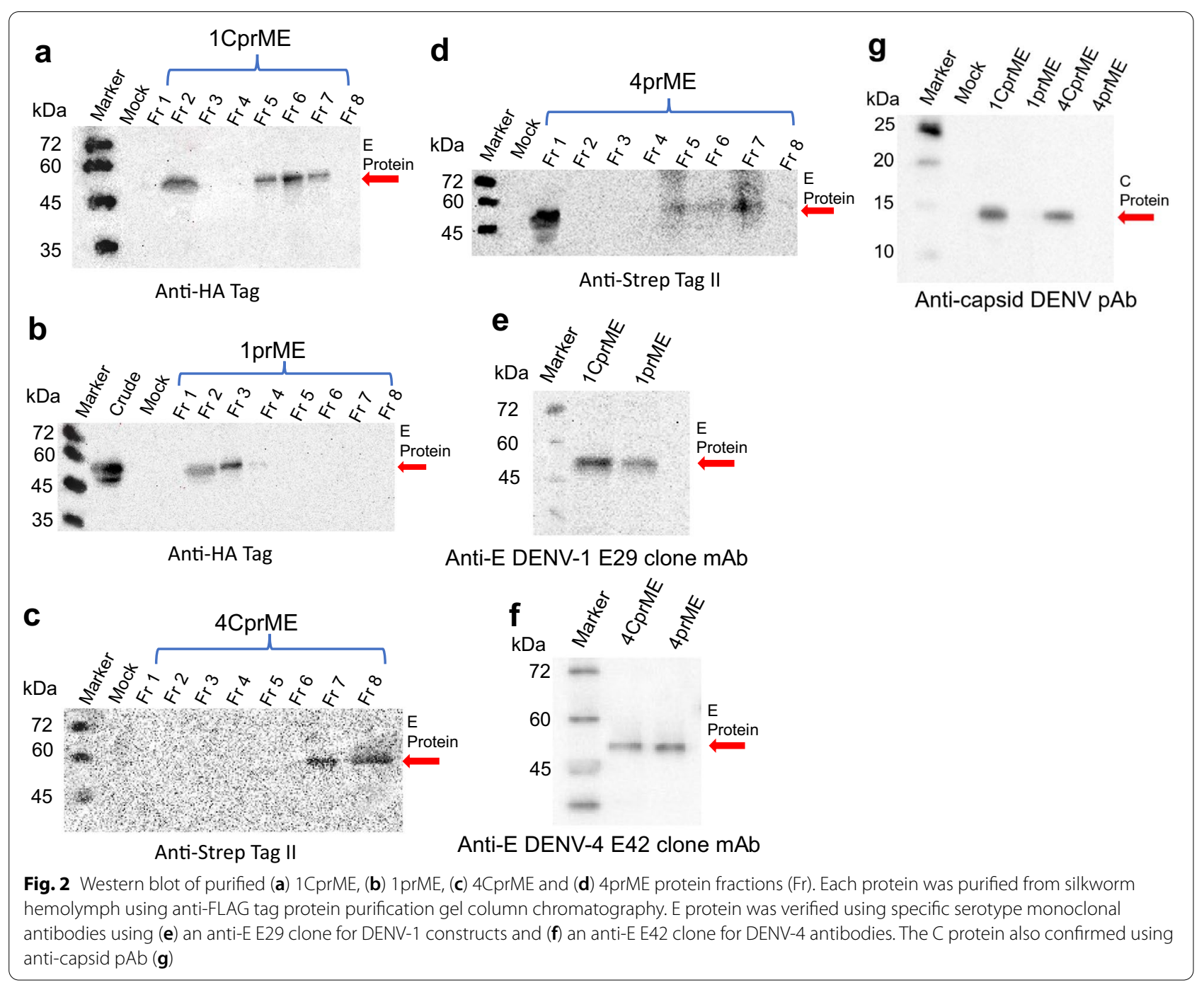

Welch t-test showed a significant difference $(\mathrm{p}<0.001)$ between DENV-LPs-patient sera reactivity to DENVLPs-positive control or PBS.

\section{DENV-LPs/1CprME, /1 prME, /4CprME and /4prME elicited virus-specific IgG}

$\mathrm{BALB} / \mathrm{c}$ mice were immunized three times at 3-week intervals with $50 \mu \mathrm{g}$ of DENV-LPs/1CprME, /1prME, /4CprME, and /4prME with an alhydrogel adjuvant injected intraperitoneally. ELISA was used to measure serum titers in mice 2 weeks after their last immunization. DENV-LPs/1CprME, /1prME, /4CprME, and /4prME induced antibody production. The anti-1CprME $\mathrm{Ab}$, anti-1prME Ab, anti-4CprME Ab, and anti-4prME $\mathrm{Ab}$ were tested for specific binding using their antigens. The anti-1CprME and anti-4CprME antibodies had high affinities for their respective DENV-LPs (Fig. 6b). Anti-1prME Ab and anti-4prME Ab, on the other hand, recognized DENV-LPs/1prME and DENV-LPs/4prME, respectively. Adjuvants increase immune responses to all antibodies, as shown in this study. Therefore, DENV-LPs/ CprME are more effective at eliciting particular antibodies than DENV-LPs/prME.

\section{Discussion}

Previously, DENV-LP/2 has expressed in silkworm larval hemolymph, and DENV-LP/3 was expressed in silkworm larval fat bodies by removing capsid-anchor in the capsid region (Utomo et al. 2019, 2020). However, the expressed 1CprME, 1prME, 4CprME, and 4prME polypeptides were detected in hemolymph by adding anchor $\mathrm{c}$ to the capsid region.

The interaction between heparin and DENV-LPs has been analyzed using multiple assays, including ELISA with immobilized heparin and ITC. Heparin binds to DENV-LPs with $K_{\mathrm{D}}$ values of 197-952 nM and $\Delta G$ values 

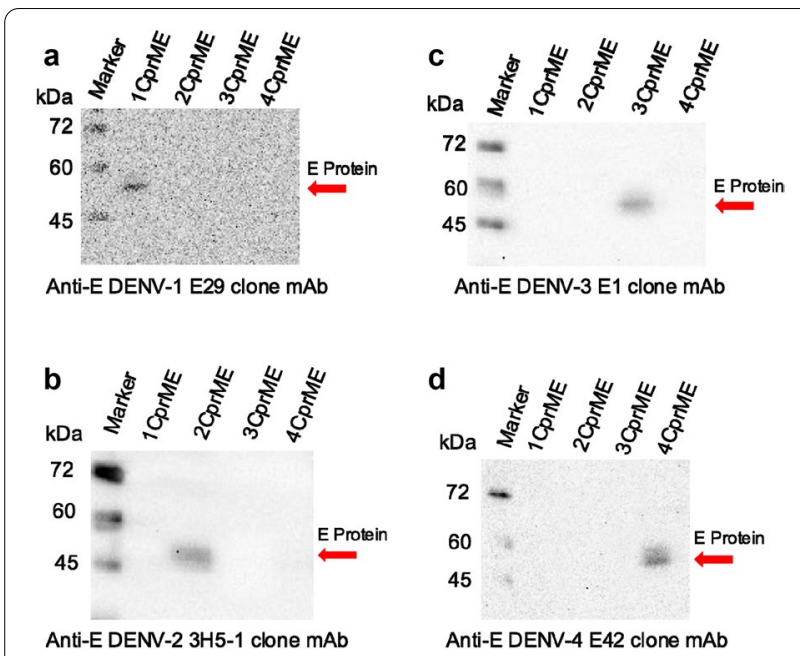

Fig. 3 Western blot of purified (a) 1CprME, (b) 1 prME, (c) 4CprME, and (d) 4prME polypeptides for the cross-reaction test was performed on the DENV-1 and DENV-4 constructs with specific serotype monoclonal antibodies for each serotype

from -8.8 to $-9.3 \mathrm{kcal} \mathrm{mol}^{-1}$ using the ITC system. According to other references, Marks et al. (2001) used $\mathrm{O}$-sulfated heparin or $\mathrm{N}$ - and $\mathrm{O}$-sulfated heparin to bind to the DENV-2 envelope protein expressed in E. coli and analyzed using SPR, yielding a $K_{\mathrm{D}}$ of $5 \mathrm{nM}$. Chen et al. (1997) used heparin to study the binding to the DENV-2 envelope protein expressed on COS-7 mammalian cells. They determined the $K_{\mathrm{D}}$ to be $15 \mathrm{nM}$ using ITC. Kim et al. (2017) used heparin to analyze the binding of the ZIKV envelope protein expressed in $E$. coli and determined the $K_{\mathrm{D}}$ to be $433 \mathrm{nM}$ using SPR (Table 2).

Compared to a protein subunit, VLPs are complex molecules composed of several protein subunits. It is known that the affinity of the ligand-protein is based on the surface's interaction, leading to the conjugation within the pocket of the protein. Hence, according to the structure of the VLP, it is considered a relatively high molar mass of macromolecules which affects the equilibrium and kinetics of its protein function. Consequently, the low effective molar concentration of a VLP results in the low surface available for binding and the overall affinity of a VLP binding being underestimated. Regarding antiviral activity, sulfated heparin has a better binding ability than heparin. Therefore, sulfated heparin is used to inhibit viral infection of cells. However, unmodified heparin in the cell membrane binds and interacts with EDIII, the putative receptor-binding domain in the flavivirus $\mathrm{E}$ protein crystal structure (Frei et al. 2018; Han et al. 2018; Yang et al. 2016; Zautner et al. 2006). EDIII also contains epitopes that block viral adsorption and are targeted by many antibodies, including serotype-specific neutralizing monoclonal antibodies. The conformational flexibility of heparin might permit this molecule to more easily adopt a productive conformation for interaction with the envelope protein. Although it has only a moderate binding affinity, the envelope of DENV-LP is still recognized by heparin on the surface of the cell (Hyatt et al. 2020; Marks et al. 2001). While mammalian cells secrete proteins with correct conformations and full biological activity, insect cells offer advantages compared to those of mammalian cells compared to E. coli or yeast expression systems. The ability to introduce foreign DNA into these cells facilitates a better understanding of the transcriptional, translational, and posttranslational machinery in mammalian cells (Gray 2001; Ikonomou et al. 2003).

The antigens of 1 CprME, 1prME, 4CprME, and 4prME also showed reactivity to patient sera high affinity in the direct ELISA. Mixed sera of dengue patients can react to many types of nonspecific DENV epitopes. The strongly correlated reactivities of patient sera with DENV-LPs indicated that the same epitope(s) were displayed on these DENV-LPs. However, there will be a marked difference in the level of antibody reactivity. In other words, the epitope(s) displayed on the DENV-LP surface is comparable with those of the native dengue virus (Danko et al. 2018; Wang et al. 2003).

DENV-LPs/1CprME, /1prME, /4CprME, and /4prME could generate IgG antibody levels since many VLPs include structural or molecular characteristics that give certain auto-immunostimulatory qualities. These features enable VLPs to induce immunological responses without adjuvants. Nevertheless, adjuvants may enhance vaccination immunogenicity and encourage activating a specific type of immune response when combined with VLP vaccines (Cimica and Galarza 2017; Donaldson et al. 2018; Müller et al. 2020). Our ITC data indicate that DENV-LP/1CprME and DENV-LPs/4CprME have a lower $K_{\mathrm{D}}$ than DENV-LP/1prME and DENV-LPs/4prME. This demonstrates that the CprME constructs have a higher affinity binding than the prME constructs. Those reactions can be harnessed to perform work inside the body. The IgG elicitation in mice confirmed DENV-LP/ CprMEs elicit a stronger immune response than DENVLPs/prMEs, which indicates CprME can easily bind to a heparin-like receptor on the surface of the cells compared to prME. This is supported by the results on heparin-binding assays, as the CprME has 4 times lower $K_{\mathrm{D}}$ value than prME. This also indicates that the EDIII might be displayed well on the envelope region of the DENVLP/CprMEs, so it can provide better activity in provoking an immune response in mice.

Furthermore, including capsid protein in the VLP design might also provide an additional antigen and better immunogenicity. When mice were immunized with 


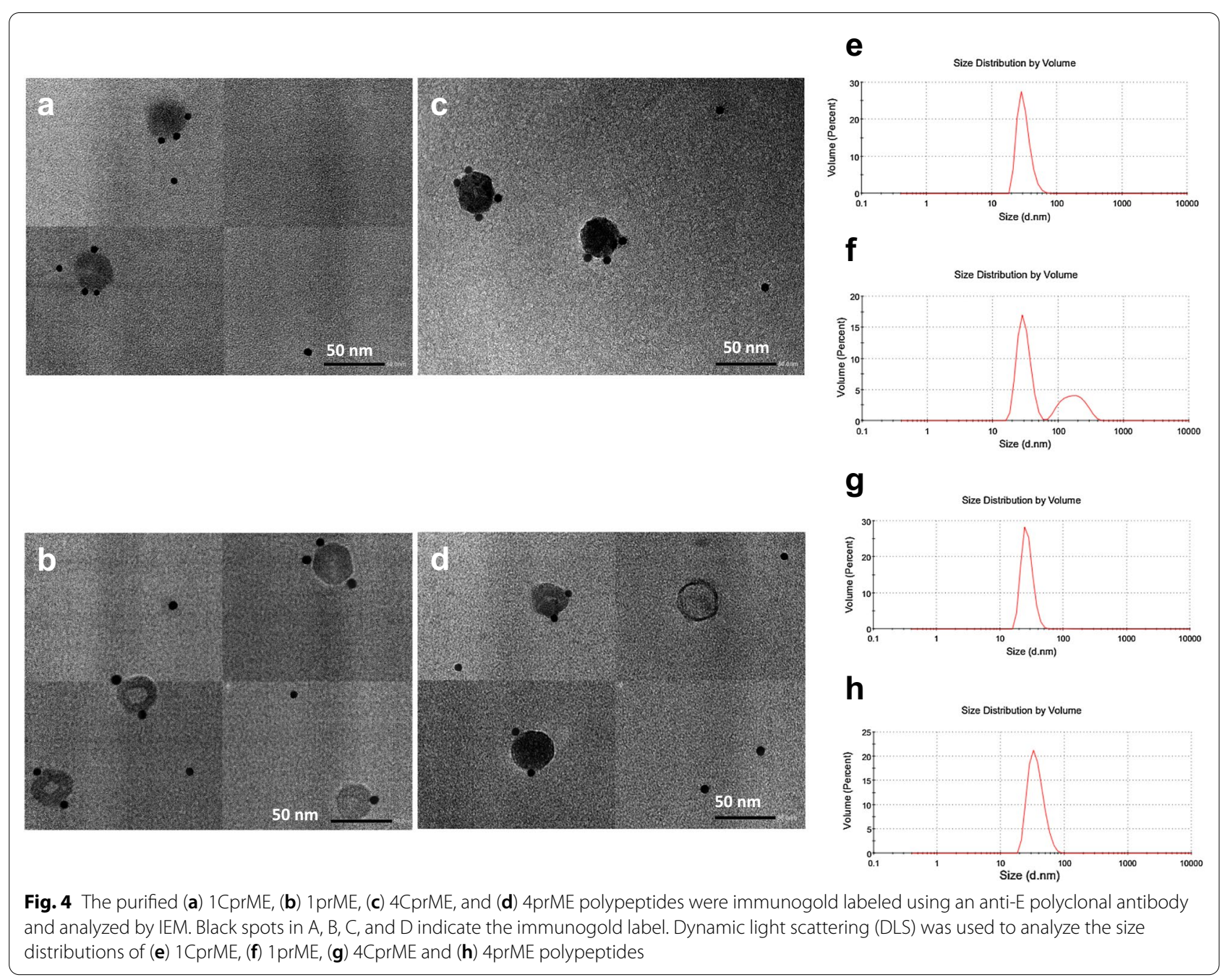

flavivirus VLPs, CprME VLPs exhibited superior antigenicity to prME VLPs. Due to the superiority of the CprME VLP, a capsid should be included in the vaccine to improve immunity. This repetitive protein structure can boost innate immunity and prompt B cells to directly generate neutralizing antibodies (Garg et al. 2019; Nooraei et al. 2021). Each DENV serotype carries the conserved antibody epitope incorporated in the $\mathrm{N}$ - and $\mathrm{C}$-terminal regions of the $\mathrm{C}$ protein and is efficiently recognized by dengue patients exposed to primary and secondary infections from other serotypes. The C-protein central region has an epitope of the peptide, primarily targeted by serotype-specific antibodies (Alves et al. 2016; Nadugala et al. 2017; Rana et al. 2018).

\section{Abbreviations}

Ab: Antibody; C: Capsid protein; DENV: Dengue virus; DENV-LP: Dengue viruslike particle; $K_{\mathrm{a}}$ : Association constant; $K_{\mathrm{D}}$ : Dissociation constant; DLS: Dynamic light scattering; E: Envelope protein; ELISA: Enzyme-linked immunosorbent assay; EDIII: Envelope protein domain III; $\Delta$ G: Gibbs free energy; HRP: Horseradish peroxidase; IEM: Immunoelectron microscopy; ITC: Isothermal Titration Calorimetry; M: Membrane protein; PBS: Phosphate-buffered saline; PBST: Phosphate-buffered saline containing $0.1 \%$ Tween 20; PCR: Polymerase chain reaction; prM: Premembrane protein; TBS: Tris-buffered saline; TBST: Tris-buffered saline containing 0.1\% Triton X-100; TEM: Transmission electron microscopy; TMB: 3.3',5.5'-Tetramethylbenzidine; VLP: Viral-like particle; WHO: World health organization.

\section{Supplementary Information}

The online version contains supplementary material available at https://doi. org/10.1186/s13568-022-01353-6.

Additional file 1: Fig. S1. Expression of 1CprME, 1 prME, 4CprME and 4prME polypeptides in silkworm larvae.

\section{Acknowledgements}

We would like to thank Dr. Etik Mardliati, Mr. Julham Effendi of the Center of Pharmaceutical and Medical Technology, National Research and Innovation Agency (BRIN), Indonesia, for the animal experiments. 

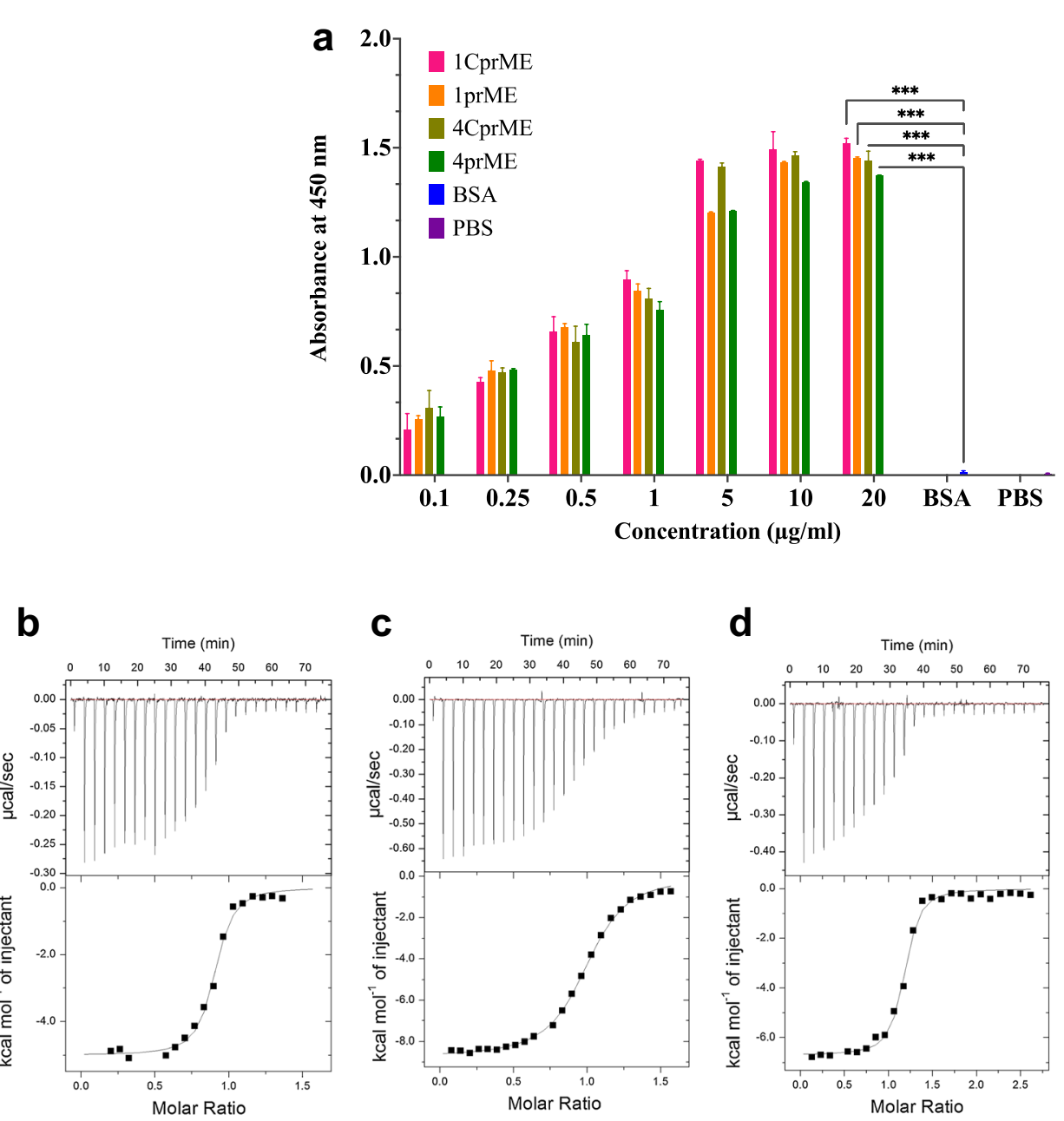

C

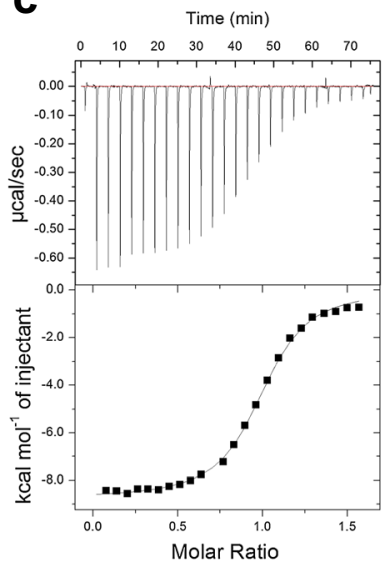

d

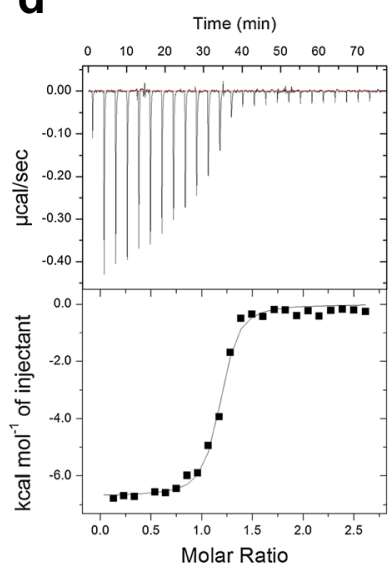

e

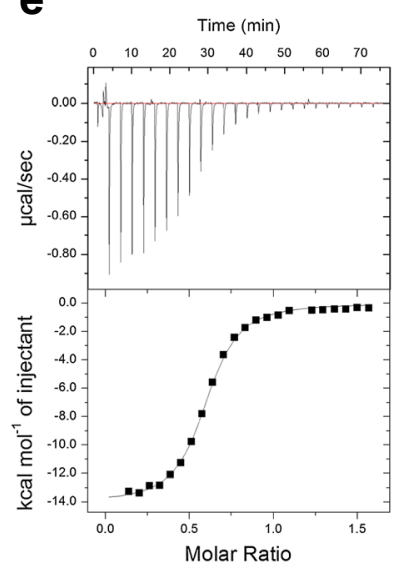

Fig. 5 a Binding assay of DENV-LPS/1CprME, /1 prME, /4CprME, and /4prME to heparin using ELISA. Heparin (1.8 ng) was coated onto each well of an ELISA plate, and each amount of purified protein was used for this ELISA, which was carried out according to the protocol described in the Materials and methods (Welch t-test, ${ }^{*} \mathrm{p}<0.05,{ }^{* *} \mathrm{p}<0.01$, ${ }^{* * *} \mathrm{p}<0.001$ ). $\mathbf{b}-\mathbf{e}$ The binding activities between DENV-LPs $/ 1 \mathrm{CprME}, / 1 \mathrm{prME}, / 4 \mathrm{CprME}$, and /4prME toward heparin were examined by ITC

Table 2 The binding affinity of DENV-LPs towards heparin

\begin{tabular}{lclllllll}
\hline Protein & $\boldsymbol{K}_{\mathbf{D}}(\mathbf{n M})$ & $\boldsymbol{K}_{\mathbf{a}}\left(\mathbf{M}^{-\mathbf{1}}\right)$ & $\mathbf{N}$ & $\boldsymbol{\Delta} \mathbf{G}\left(\mathbf{k c a l ~} \mathbf{~ m o l}^{\mathbf{- 1}}\right)$ & Ligand & Host & Method & Refs. \\
\hline DENV-LP/1CprME & 235.2 & $4.44 \times 10^{6}$ & 0.88 & -8.92 & Heparin & B. mori & ITC & This study \\
DENV-LP/1 prME & 952.4 & $1.05 \times 10^{6}$ & 0.98 & -9.28 & Heparin & B. mori & ITC & This study \\
DENV-LP/4CprME & 197.6 & $5.06 \times 10^{6}$ & 1.14 & -8.99 & Heparin & B. mori & ITC & This study \\
DENV-LP/4prME & 819.7 & $1.22 \times 10^{6}$ & 0.58 & -8.85 & Heparin & B. mori & ITC & This study \\
DENV-2 E protein & 5.0 & - & - & - & O-sulfated heparin & E.coli & SPR & Marks et al. (2001) \\
DENV-2 E protein & 5.0 & - & - & - & N- and O-sulfated heparin & E.coli & SPR & Marks et al. (2001 \\
DENV-2 E protein & 15.0 & - & - & - & Heparin & COS-7 & ITC & Chen et al. (1997) \\
ZIKV-E & 433.0 & - & - & - & E.coli & SPR & Kim et al. (2017) \\
\hline
\end{tabular}




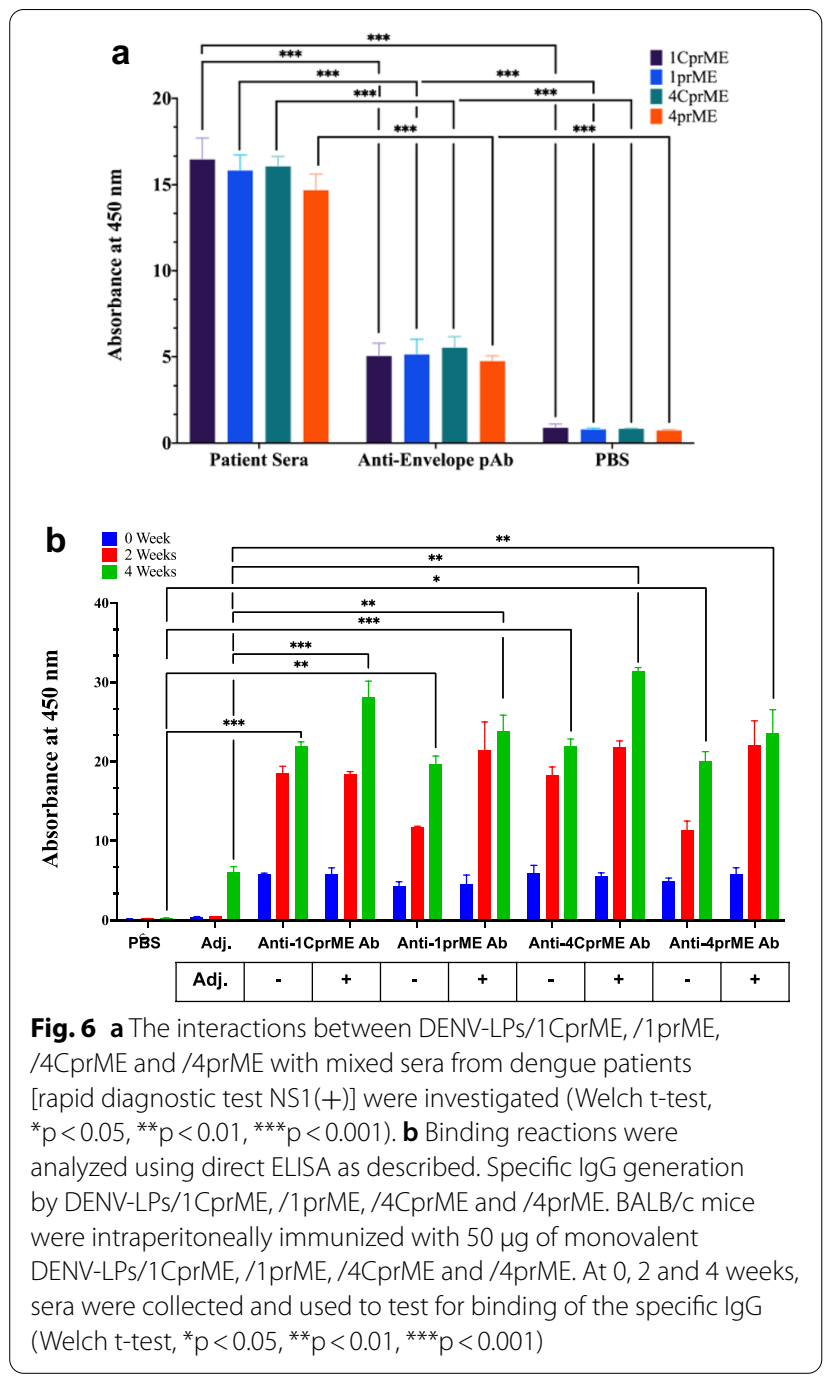

\section{Authors' contributions}

DISU was the main researcher for this study and was involved with the experimental design and operation. SP participated in animal experiments and provided resources, respectively. EYP provided ideas, funded the research, revised the manuscript, and supervised this study. All authors read and approved the manuscript.

\section{Funding}

This work has been funded by the Japan Society for the Promotion of Science (JSPS) KAKENHI Grant-in-Aid for Scientific Research (A) (Grant No. 20H00411) and partly (16H02544) and partly by the Heiwa Nakajima Foundation's Asian region priority academic research grant.

\section{Availability of data and materials}

All the data and materials have been provided in the main manuscript.

\section{Declarations}

\section{Ethical approval and consent to participate}

Dengue patient sera were obtained from the Centre of Pharmaceutical and Medical Technology, National Research and Innovation Agency, Jakarta, Indonesia. Serum collection protocols were reviewed and approved by the Health Research Ethics Committee-University of Indonesia and Cipto
Mangunkusumo Hospital (HREC-FMUI/CMH) (approval no. KET-1358/UN2. F1/ETIK/PPM.00.02/2020). Animal experimental protocols were reviewed and approved by the Research Ethical Committee of the Faculty of Medicine, Universitas Indonesia (No. KET-721/UN2.F1/ETIK/PPM.00.02/2021). All applicable international, national, and/or institutional guidelines for the care and use of animals were followed.

\section{Consent for publication}

Not applicable.

\section{Competing interests}

The authors declare that they have no competing interests.

\section{Author details}

${ }^{1}$ Laboratory of Biotechnology, Department of Bioscience, Graduate School of Science and Technology, Shizuoka University, 836 Ohya, Suruga-ku, Shizuoka 422-8529, Japan. ${ }^{2}$ Center of Pharmaceutical and Medical Technology, National Research and Innovation Agency (BRIN), Jl. Kawasan Puspiptek, Gedung I LAPTIAB, Kota Tangerang Selatan, Banten 15314, Indonesia. ' 'Laboratory of Biotechnology, Research Institute of Green Science and Technology, Shizuoka University, 836 Ohya, Suruga-ku, Shizuoka 422-8529, Japan.

Received: 16 November 2021 Accepted: 22 January 2022

Published online: 31 January 2022

\section{References}

Alves R, Pereira LR, Fabris DLN, Salvador FS, Santos RA, Zanotto PMA, Romano CM, Amorim JH, Ferreira LCS (2016) Production of a recombinant dengue virus 2 NS5 protein and potential use as a vaccine antigen. Clin Vaccine Immunol 23(6):460-469. https://doi.org/10.1128/CVI.00081-16

Bhatt P, Sabeena SP, Varma M, Arunkumar G (2021) Current understanding of the pathogenesis of dengue virus infection. Curr Microbiol 78(1):17-32. https://doi.org/10.1007/s00284-020-02284-w

Boonyakida J, Xu J, Satoh J, Nakanishi T, Mekata T, Kato T, Park EY (2021) Identification of antigenic domains and peptides from VP15 of white spot syndrome virus and their antiviral effects in Marsupenaeus japonicus. Sci Rep 11(1):12766. https://doi.org/10.1038/s41598-021-92002-8

Cimica V, Galarza JM (2017) Adjuvant formulations for virus-like particle (VLP) based vaccines. Clin Immunol 183:99-108. https://doi.org/10.1016/j.clim. 2017.08.004

Chen Y, Maguire T, Hileman RE, Fromm JR, Esko JD, Linhardt RJ, Marks RM (1997) Dengue virus infectivity depends on envelope protein binding to target cell heparan sulfate. Nat Med 3(8):866-871. https://doi.org/10. 1038/nm0897-866

Danko JR, Kochel T, Teneza-Mora N, Luke TC, Raviprakash K, Sun P, Simmons M, Moon JE, De La Barrera R, Martinez LJ, Thomas SJ, Kenney RT, Smith L, Porter KR (2018) Safety and immunogenicity of a tetravalent dengue DNA vaccine administered with a cationic lipid-based adjuvant in a phase 1 clinical trial. Am J Trop Med Hyg 98(3):849-856. https://doi.org/10.4269/ ajtmh.17-0416

Donaldson B, Lateef Z, Walker GF, Young SL, Ward VK (2018) Virus-like particle vaccines: immunology and formulation for clinical translation. Expert Rev Vaccines 17(9):833-849. https://doi.org/10.1080/14760584.2018.1516552

Duff MR Jr, Grubbs J, Howell EE (2011) Isothermal titration calorimetry for measuring macromolecule-ligand affinity. J vis Exp 55:2796. https://doi. org/10.3791/2796

Frei JC, Wirchnianski AS, Govero J, Vergnolle O, Dowd KA, Pierson TC, Kielian M, Girvin ME, Diamond MS, Lai JR (2018) Engineered dengue virus domain III proteins elicit cross-neutralizing antibody responses in mice. J Virol 92(18):e01023-e1118. https://doi.org/10.1128/JVI.01023-18

Fujita R, Hino M, Ebihara T, Nagasato T, Masuda A, Lee JM, Fujii T, Mon H, Kakino K, Nagai R, Tanaka M, Tonooka Y, Moriyama T, Kusakabe T (2020) Efficient production of recombinant SARS-CoV-2 spike protein using the baculovirus-silkworm system. Biochem Biophys Res Commun 529(2):257-262. https://doi.org/10.1016/j.bbrc.2020.06.020

Garg H, Mehmetoglu-Gurbuz T, Ruddy GM, Joshi A (2019) Capsid containing virus like particle vaccine against zika virus made from a stable cell line. Vaccine 37(48):7123-7131. https://doi.org/10.1016/j.vaccine.2019.09.093 
Gray D (2001) Overview of protein expression by mammalian cells. Curr Protocol Protein Sci. Chapter 5(1):Unit5.9-Unit5.9. https://doi.org/10.1002/ 0471140864.ps0509s10

Han S-C, Huy N-X, Kim M-Y (2018) Enhanced expression of dengue virus EDIIIbased tetravalent antigen protein using transgenic rice callus. Plant Biotechnol Rep 12(3):207-215. https://doi.org/10.1007/s11816-018-0487-6

Hyatt JG, Prévost S, Devos JM, Mycroft-West CJ, Skidmore MA, Winter A (2020) Molecular changes in dengue envelope protein domain III upon interaction with glycosaminoglycans. Pathogens 9(11):935. https://doi.org/10. 3390/pathogens9110935

Ikegaya M, Miyazaki T, Park EY (2021) Biochemical characterization of Bombyx mori a- $N$-acetylgalactosaminidase belonging to the glycoside hydrolase family 31. Insect Mol Biol 30(4):367-378. https://doi.org/10.1111/imb. 12701

Ikonomou L, Schneider YJ, Agathos SN (2003) Insect cell culture for industrial production of recombinant proteins. Appl Microbiol Biotechnol 62(1):1-20. https://doi.org/10.1007/s00253-003-1223-9

Kato T, Kajikawa M, Maenaka K, Park EY (2010) Silkworm expression system as a platform technology in life science. Appl Microbiol Biotechnol 85(3):459-470. https://doi.org/10.1007/s00253-009-2267-2

Kim SY, Zhao J, Liu X, Fraser K, Lin L, Zhang X, Zhang F, Dordick JS, Linhardt RJ (2017) Interaction of zika virus envelope protein with glycosaminoglycans. Biochemistry 56(8):1151-1162. https://doi.org/10.1021/acs.bioch em.6b01056

Krol E, Brzuska G, Szewczyk B (2019) Production and biomedical application of flavivirus-like particles. Trends Biotechnol 37(11):1202-1216. https://doi. org/10.1016/j.tibtech.2019.03.013

Maesaki R, Satoh R, Taoka M, Kanaba T, Asano T, Fujita C, Fujiwara T, Ito Y, Isobe T, Hakoshima T, Maenaka K, Mishima M (2014) Efficient and cost effective production of active-form human PKB using silkworm larvae. Sci Rep 4(1):6016. https://doi.org/10.1038/srep06016

Marks RM, Lu H, Sundaresan R, Toida T, Suzuki A, Imanari T, Hernáiz MJ, Linhardt RJ (2001) Probing the interaction of dengue virus envelope protein with heparin: assessment of glycosaminoglycan-derived inhibitors. J Med Chem 44(13):2178-2187. https://doi.org/10.1021/jm000412i

Müller H, Fehling SK, Dorna J, Urbanowicz RA, Oestereich L, Krebs Y, Kolesnikova L, Schauflinger M, Krähling V, Magassouba NF, Fichet-Calvet E, Ball JK, Kaufmann A, Bauer S, Becker S, von Messling V, Strecker T (2020) Adjuvant formulated virus-like particles expressing native-like forms of the lassa virus envelope surface glycoprotein are immunogenic and induce antibodies with broadly neutralizing activity. Npj Vaccines 5(1):71. https://doi.org/10.1038/s41541-020-00219-x

Nadugala MN, Jeewandara C, Malavige GN, Premaratne PH, Goonasekara CL (2017) Natural antibody responses to the capsid protein in sera of dengue infected patients from Sri Lanka. PLoS ONE 12(6):e0178009. https:// doi.org/10.1371/journal.pone.0178009

Nishiura H, Halstead SB (2007) Natural history of dengue virus (DENV) - 1 and DENV—4 infections: reanalysis of classic studies. J Infect Dis 195(7):10071013. https://doi.org/10.1086/511825

Noad R, Roy P (2003) Virus-like particles as immunogens. Trends Microbiol 11(9):438-444. https://doi.org/10.1016/S0966-842x(03)00208-7

Nooraei S, Bahrulolum H, Hoseini ZS, Katalani C, Hajizade A, Easton AJ, Ahmadian G (2021) Virus-like particles: preparation, immunogenicity and their roles as nanovaccines and drug nanocarriers. J Nanobiotechnol 19(1):59. https://doi.org/10.1186/s12951-021-00806-7

Rana J, Slon Campos JL, Leccese G, Francolini M, Bestagno M, Poggianella M, Burrone OR (2018) Role of capsid anchor in the morphogenesis of zika virus. JVirol 92(22):e01174-e1218. https://doi.org/10.1128/JVI.01174-18

Redoni M, Yacoub S, Rivino L, Giacobbe DR, Luzzati R, Di Bella S (2020) Dengue: status of current and under-development vaccines. Rev Med Virol 30(4):e2101. https://doi.org/10.1002/rmv.2101

Roldao A, Mellado MC, Castilho LR, Carrondo MJ, Alves PM (2010) Virus-like particles in vaccine development. Expert Rev Vaccines 9(10):1149-1176. https://doi.org/10.1586/erv.10.115

Sang S, Liu-Helmersson J, Quam MBM, Zhou H, Guo X, Wu H, Liu Q (2019) The evolutionary dynamics of DENV 4 genotype I over a 60-year period. PLoS Negl Trop Dis 13(7):e0007592. https://doi.org/10.1371/journal.pntd.00075 92

Suhaimi H, Hiramatsu R, Xu J, Kato T, Park EY (2019) Secretory Nanoparticles of Neospora caninum profilin-fused with the transmembrane domain of GP64 from silkworm hemolymph. Nanomaterials 9(4):593. https://doi. org/10.3390/nano9040593

Utomo DIS, Hirono I, Kato T, Park EY (2019) Formation of virus-like particles of the dengue virus serotype 2 expressed in silkworm larvae. Mol Biotechnol 61(11):852-859. https://doi.org/10.1007/s12033-019-00210-5

Utomo DIS, Pambudi S, Sjatha F, Kato T, Park EY (2020) Production of dengue virus-like particles serotype-3 in silkworm larvae and their ability to elicit a humoral immune response in mice. AMB Express 10(1):147. https://doi. org/10.1186/s13568-020-01087-3

Villabona-Arenas CJ, Zanotto PMdA (2013) Worldwide spread of dengue virus type 1. PLoS ONE 8(5):e62649. https://doi.org/10.1371/journal.pone. 0062649

Vipin Kumar Deo TK (2012) Functional virus-like particles production using silkworm and their application in life science. J. Biotechnol. Biomaterial. s9(01):7 doi:https://doi.org/10.4172/2155-952x.S9-001

Wang X, Wang Z, Christensen ND, Dillner J (2003) Mapping of human serumreactive epitopes in virus-like particles of human papillomavirus types 16 and 11. Virology 311(1):213-221. https://doi.org/10.1016/S0042-6822(03) 00179-X

Yang J, Zou L, Yang Y, Yuan J, Hu Z, Liu H, Peng H, Shang W, Zhang X, Zhu J, Rao X (2016) Superficial vimentin mediates DENV-2 infection of vascular endothelial cells. Sci Rep 6:38372. https://doi.org/10.1038/srep38372

Yousaf M, Junaid K, Iqbal MS, Aslam I, Ahmad S, Aqeel M, Ashfaq UA, Khaliq S, Ghani MU, Waqar N (2018) Analysis of dengue virus burden and serotypes pattern in Faisalabad, 2016-2017. Future Virol 13(4):245-251. https://doi. org/10.2217/fvl-2017-0155

Zautner AE, Jahn B, Hammerschmidt E, Wutzler P, Schmidtke M (2006) N- and 6-O-sulfated heparan sulfates mediate internalization of coxsackievirus B3 variant PD into CHO-K1 cells. J Virol 80(13):6629-6636. https://doi.org/10. 1128/JVI.01988-05

\section{Publisher's Note}

Springer Nature remains neutral with regard to jurisdictional claims in published maps and institutional affiliations.

\section{Submit your manuscript to a SpringerOpen ${ }^{\circ}$ journal and benefit from:}

- Convenient online submission

- Rigorous peer review

- Open access: articles freely available online

- High visibility within the field

- Retaining the copyright to your article

Submit your next manuscript at $>$ springeropen.com 